SP ESL42

\title{
SOIL, WATER AND LAND USE:
}

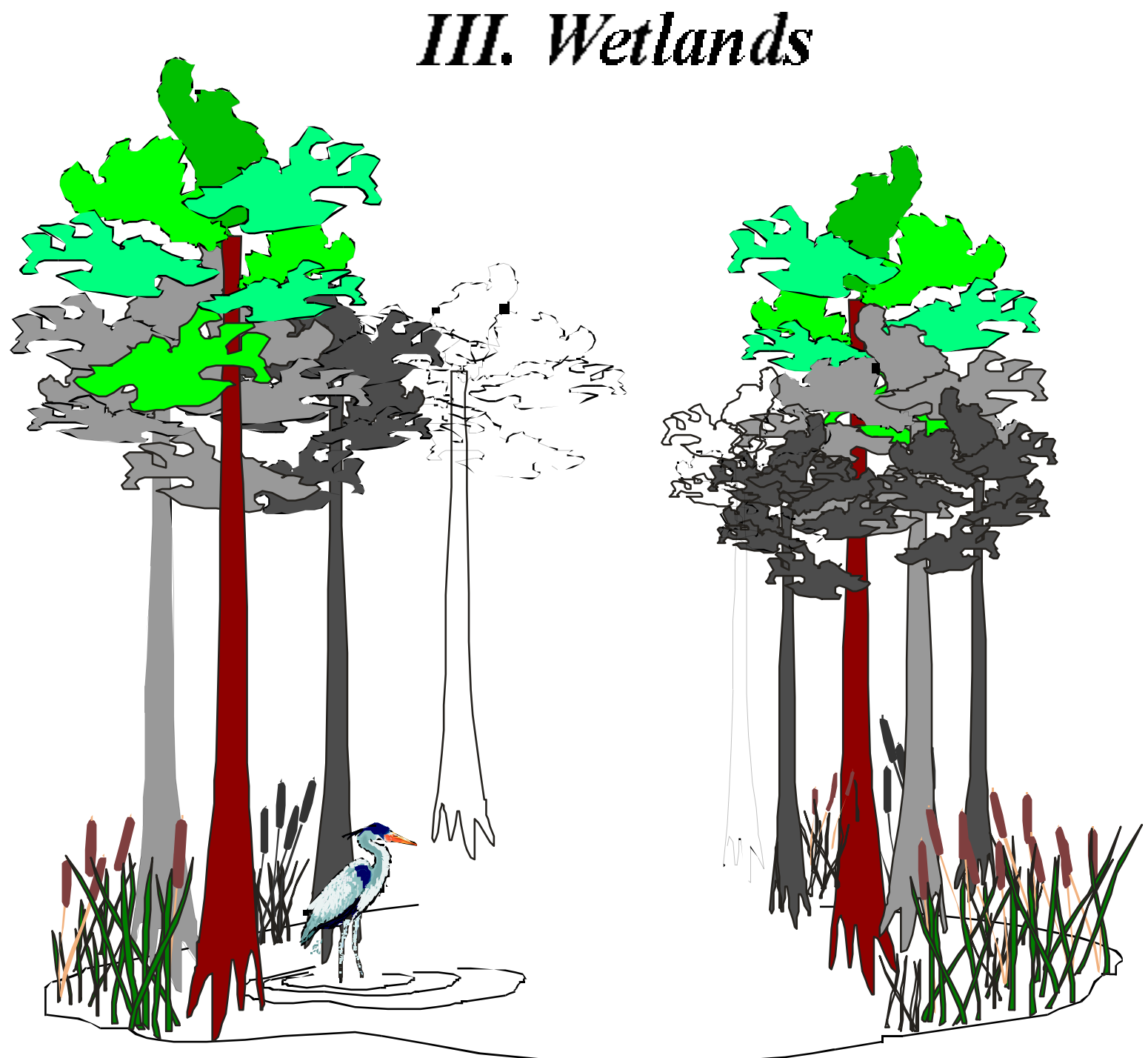

(ब)

A Soil and Water Education Kit

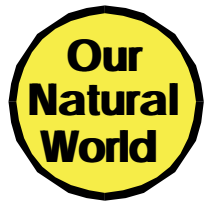


SP ESL42

$4 H$ ESL42

\section{Soil, Water and Land Use: III. Wetlands}
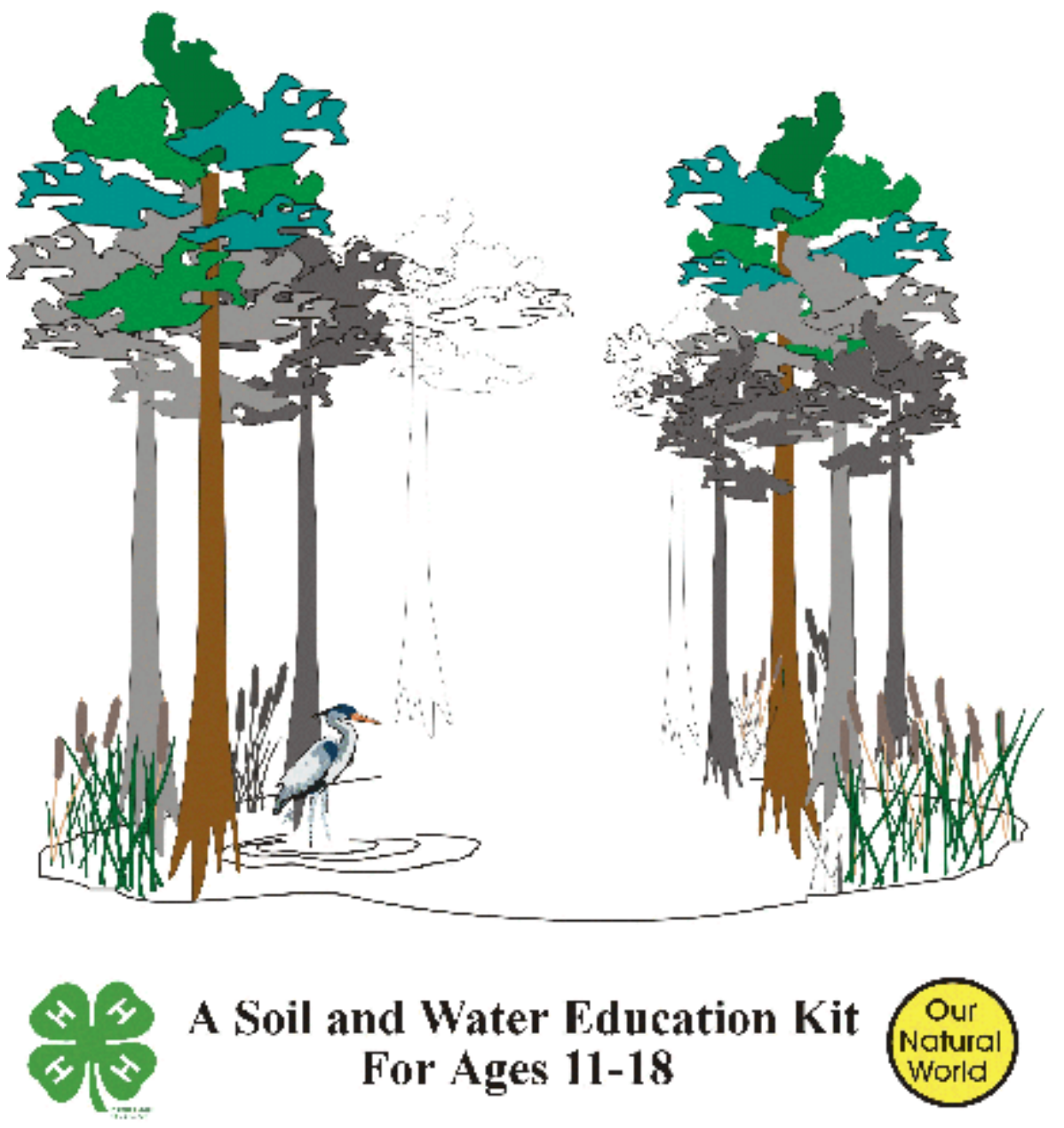

Produced jointly by the Soil and Water Science Department and the 4-H Youth Development Program, University of Florida Cooperative Extension, Institute of Food and Agricultural Sciences, University of Florida, Published March 2002.

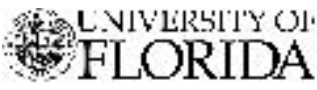

\section{HXTENSION}

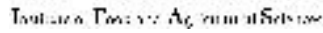

COOPERATIVE EXTENSION SERVICE, UNIVERSITY OF FLORIDA, INSTITUTE OF FOOD AND AGRICULTURAL SCIENCES, Christine Taylor Waddill, Director, in cooperation with the United States Department of Agriculture, publishes this information to further the purpose of the May 8 and June 30, 1914 Acts of Congress; and is authorized to provide research, educational information and other services only to individuals and institutions that function without regard to race, color, age, sex, disability or national origin. The information in this publication is available in alternate formats. Information on copies for purchase is available from IFAS-Extension Bookstore, University of Florida, PO Box 110011, Gainesville, FL 32611-0011 or visit our Web site at: ifasbooks.ufl.edu. Information about alternate formats is available from IFAS Communication Services, University of Florida, PO Box 110810, Gainesville, FL 32611-0810. This information was published March 2002 as SPESL42 and 4HESL42, Florida Cooperative Extension Service. Reviewed March 2002. Printed March 2002 


\section{Soil, Water and Land Use: III. Wetlands Leader's Activity Guide A 4-H Activity Guide for 11-18-year-olds}

\section{PREFACE}

Wetlands were once considered wastelands - areas which could be drained and put to better use. Research in the last 30 years has shown that wetlands are some of the most important and productive ecosystems on earth. Considerable effort has gone into identifying the benefits of wetlands and working toward their conservation.

The goal of Soil Water and Land Use: III. Wetlands is to enhance the understanding of wetlands from their uniqueness as ecosystems to their benefits for humans. The conservation and restoration of wetlands is often an emotive issue. Through better understanding of wetlands, students will be able to make more responsible and informed decisions about these natural resources.

Most of the learning activities in this notebook use simple and inexpensive materials. The activities lend themselves to group work and participant-led conclusions to support the given background materials. These activities follow the belief that learning should be a combination of discovery, discussion and gaining from those who are more knowledgeable. In addition, each lesson contains several pages of student background text. This information is written with young people in mind. Concepts are simple and text is interspersed with helpful figures and graphics. The background text will likely be of benefit to instructors as well.

This curriculum package is designed for middle and high school students, although activities can be modified to work with almost any age group. Correlations to the Florida Sunshine State Standard benchmarks for science, math, social studies and language arts are provided for middle and high school levels. FCAT-like reading and writing prompts are included when possible under the "Apply" section of many activities. Since student background knowledge and experience vary enormously, educators are encouraged to choose the activities that will be most appropriate to their situation. Therefore, teachers are encouraged to choose activities most appropriate to classroom needs and time limitations.

The authors would like to acknowledge two valuable sources of information used while preparing these materials. The first is Wetlands by William J. Mitsch and James G. Gosselink. The second is Ecosystems of Florida by Ronald L. Myers and John J. Ewel. Full references for these books can be found in the reference section. 


\section{4-H ENVIRONMENTAL EDUCATION CURRICULUM FRAMEWORK}

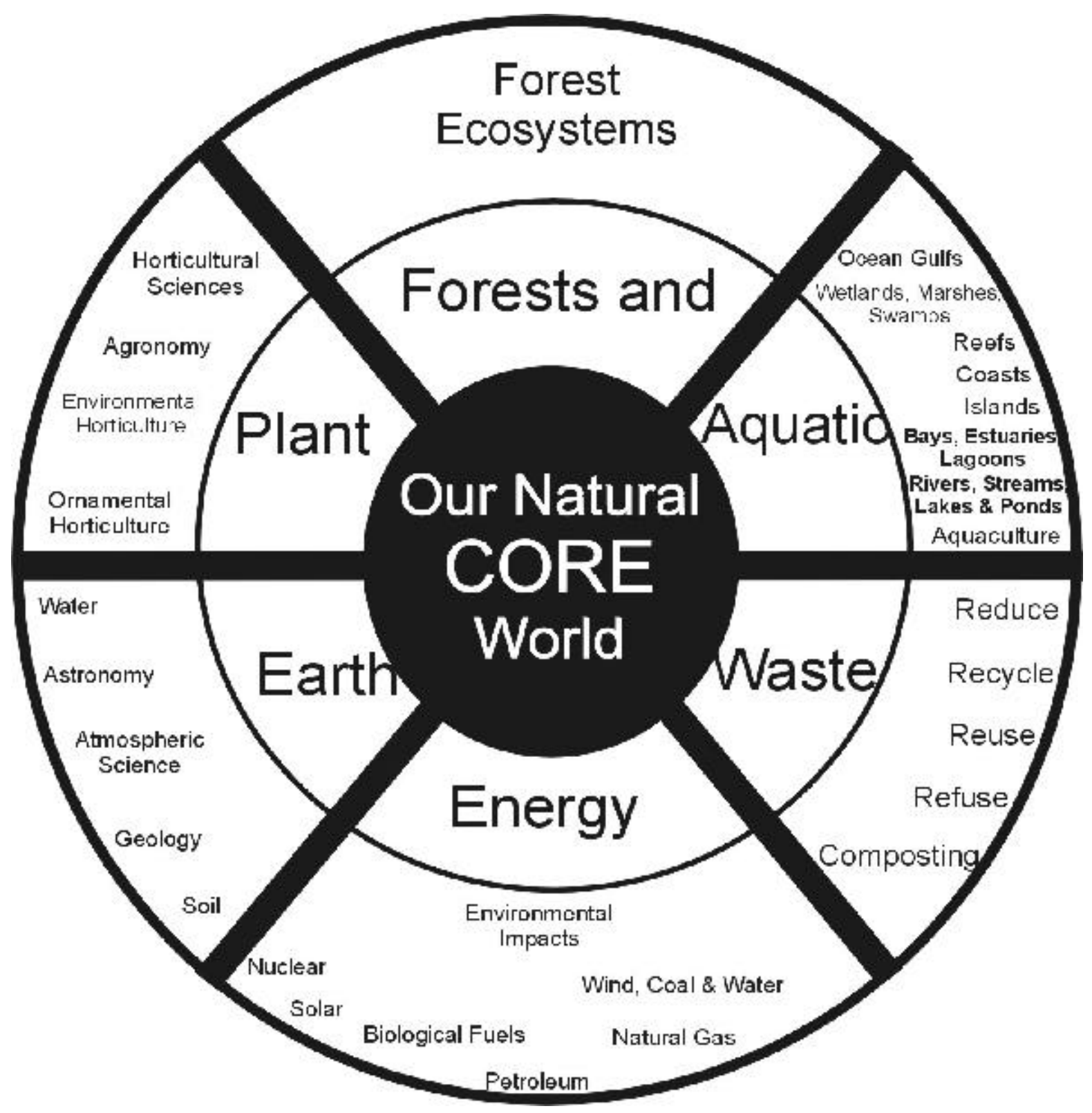




\section{TABLE OF CONTENTS}

\section{INTRODUCTION}

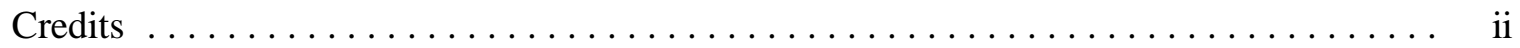

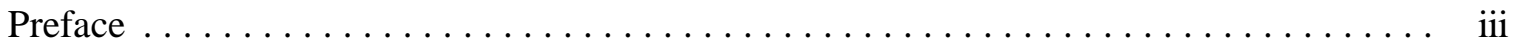

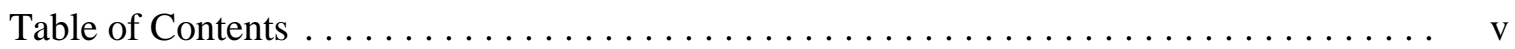

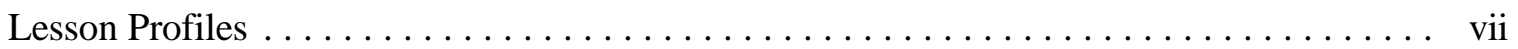

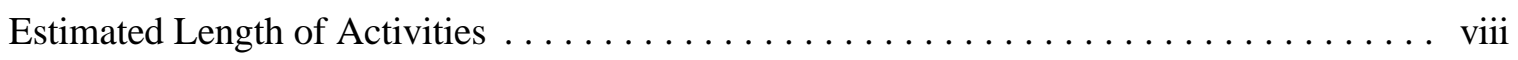

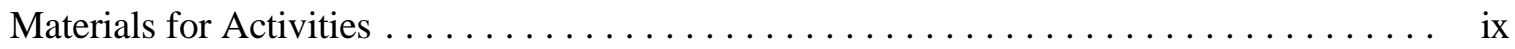

Experiential Learning Model $\ldots \ldots \ldots \ldots \ldots \ldots \ldots \ldots \ldots \ldots \ldots \ldots \ldots \ldots \ldots \ldots \ldots \ldots \ldots \ldots$

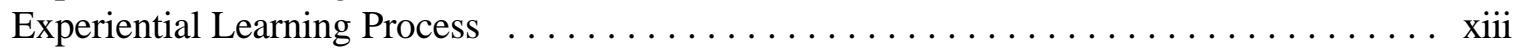

\section{WETLANDS}

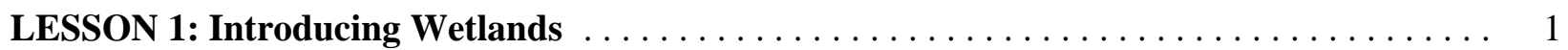

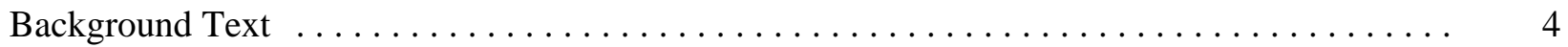

Activities

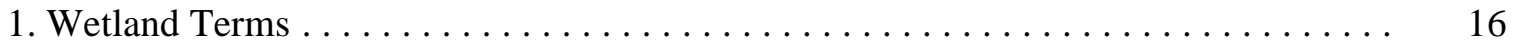

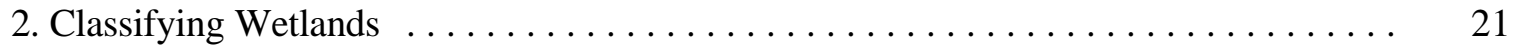

3. Carnivorous Plants .................................. 27

4. Wetlands Information Search $\ldots \ldots \ldots \ldots \ldots \ldots \ldots \ldots \ldots \ldots \ldots \ldots \ldots \ldots \ldots \ldots \ldots$

5. Where Are the Wetlands? .............................. 36

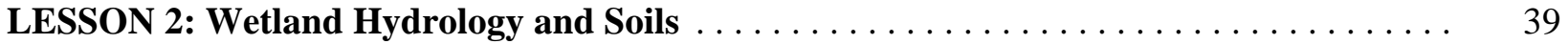

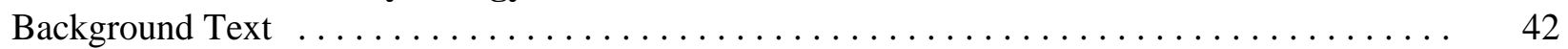

Activities

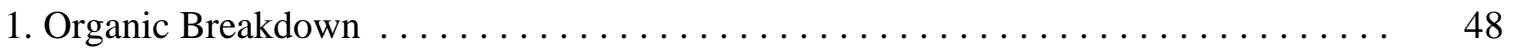

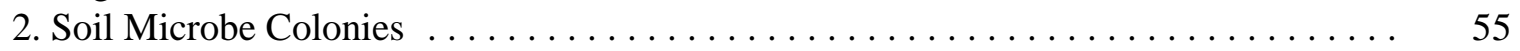

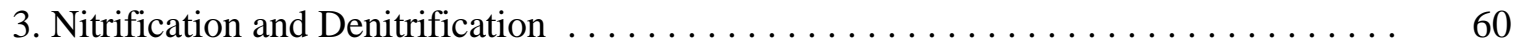

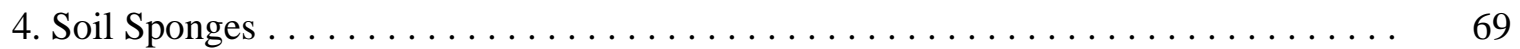

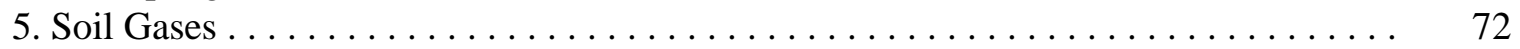

LESSON 3: The Importance of Wetlands $\ldots \ldots \ldots \ldots \ldots \ldots \ldots \ldots \ldots \ldots \ldots \ldots \ldots \ldots \ldots$

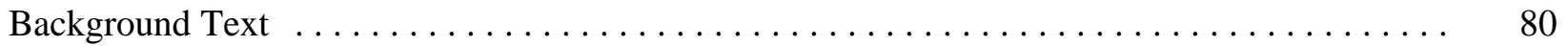

Activities

1. What's for Dinner? . . . . . . . . . . . . . . . . . . . . . . . . . . . 85

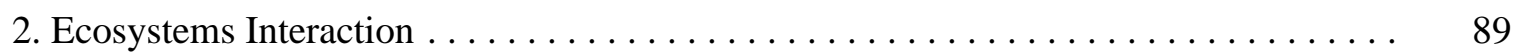

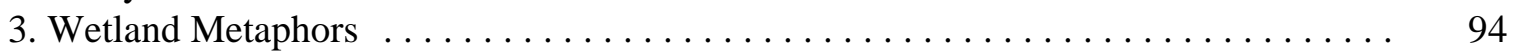

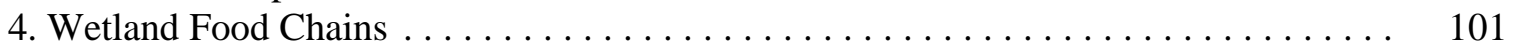

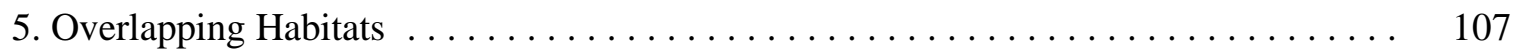

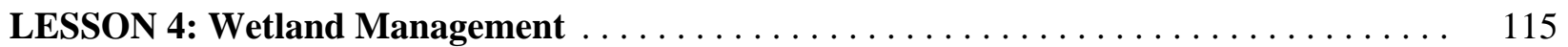

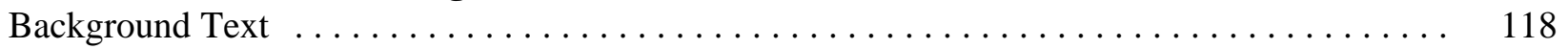

Activities

1. How Do They Help? .................................... 125

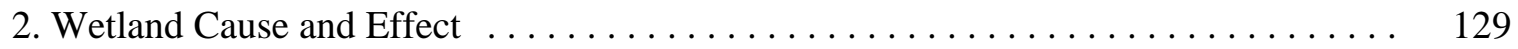

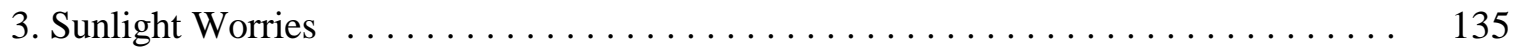

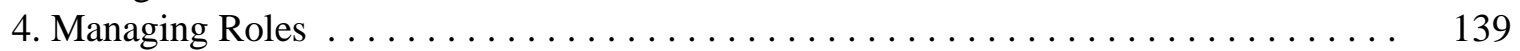




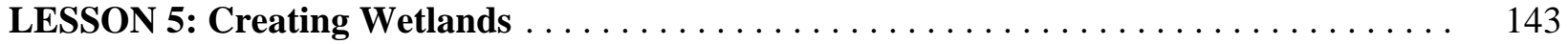

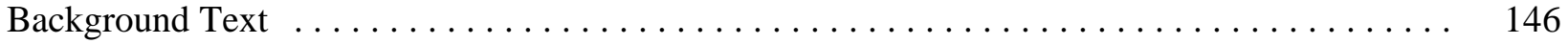

Activities

1. Flushed With Success . . . . . . . . . . . . . . . . . . . . . . . . . . . . 150

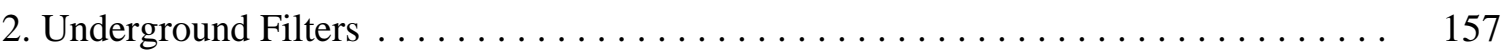

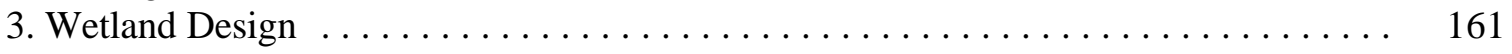

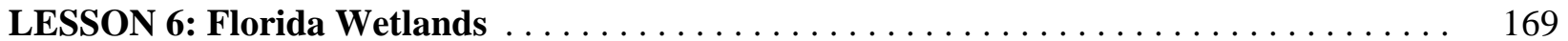

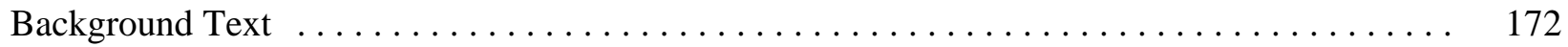

Activities

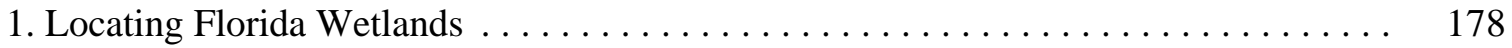

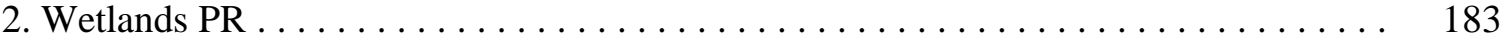

III. SUPPLEMENTAL MATERIALS

Appendix A: Wetland Area by State . . . . . . . . . . . . . . . . . . . . . . . . . 187

Appendix B: Florida Wetlands . . . . . . . . . . . . . . . . . . . . . . . . . . . . . 191

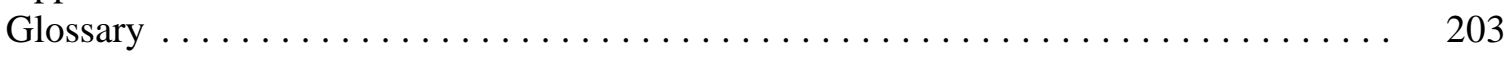

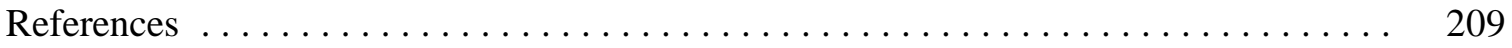

IV. EVALUATION

Suggestions for Extension and Evaluation $\ldots \ldots \ldots \ldots \ldots \ldots \ldots \ldots \ldots \ldots \ldots \ldots \ldots \ldots$ 


\section{LESSON PROFILES}

\section{Lesson One: Introducing Wetlands}

Students are introduced to the major types of freshwater and marine wetlands. Learning activities help students with the classification and terms involved with wetland definitions. Students are also encouraged to work on mapping and research skills.

\section{Lesson Two: Wetland Hydrology and Soils}

This lesson focuses on hydrology, soils and biogeochemical cycling throughout wetland ecosystems. The experiential activities deal primarily with soil and some of the microbial conversions that take place in wetland soils. These include the breakdown of organic matter and transformations along the nitrogen cycle.

\section{Lesson Three: The Importance of Wetlands}

Once students are aware of the variety and functions of wetlands, they are asked to discover the benefits of these ecosystems. Their value as producers of foodstuffs, habitats and water purification are just a few of the services wetlands perform.

\section{Lesson Four: Wetland Management}

The purpose of this lesson is to learn about the reasons for wetland losses, ongoing threats to wetlands, and current wetland management policies. Students explore the consequences of human activities on wetlands, debate the views and concerns of those involved with wetland decisions, and explore how local and national agencies work to protect wetlands.

\section{Lesson Five: Creating Wetlands}

Lesson Five introduces students to the classifications and uses of created wetlands. Students look at an existing wetland used for waste water treatment, experiment with the water-cleansing ability of mineral particles, and design their own wetland for waste water treatment.

\section{Lesson Six: Florida Wetlands}

Florida residents are encouraged to learn more about the variety, value and location of the state's wetlands. Students identify the location of various wetland systems, design ways to promote the values of Florida wetlands, and consider visiting a wetland. 